\title{
Plasma proteins in growing analbuminaemic rats fed on a diet of low-protein content
}

\author{
By J. A. JOLES ${ }^{1}$, E. H. J. M. JANSEN ${ }^{2}$, C. A. LAAN², N. WILLEKES- \\ KOOLSCHIJ N ${ }^{1}$, W. KORTLANDT ${ }^{3}$ AND H. A. KOOMANS ${ }^{1}$ \\ ${ }^{1}$ Department of Nephrology and Hypertension and ${ }^{3}$ Department of Clinical Chemistry, \\ University Hospital Utrecht, Catharijnesingel 101, 3511 GV Utrecht, The Netherlands \\ ${ }^{2}$ National Institute of Public Health and Environmental Hygiene (RIVM), \\ A. van Leeuwenhoeklaan 9, Bilthoven, The Netherlands
}

\section{(Received 1 September 1988 - Accepted 21 December 1988)}

\begin{abstract}
1. Analbuminaemic and Sprague-Dawley (control) rats were fed on low- $(60 \mathrm{~g} / \mathrm{kg}$ ) protein and control $(200 \mathrm{~g}$ protein $/ \mathrm{kg})$ diets $\mathrm{ad} \mathrm{lib}$. from weaning. Males and females were studied separately. Body-weight and plasma protein concentrations were determined at $10 \mathrm{~d}$ intervals from 25 to $75 \mathrm{~d}$ of age. Electrophoresis of plasma proteins was performed in samples from day 75 . Extracellular fluid volume was measured at $10 \mathrm{~d}$ intervals from day 45 onwards. Colloid osmotic pressure was measured in plasma and interstitial fluid (wick technique) at the
\end{abstract} start and end of the trial.

2. Body-weight increased much less on the low-protein diet than on the normal diet in both strains and sexes. The growth retardation was slightly more pronounced in the male analbuminaemic rats than in the male Sprague-Dawley controls.

3. Plasma protein concentration increased during normal growth in all groups, particularly in the female analbuminaemic rats. This increase was reduced by the $60 \mathrm{~g}$ protein $/ \mathrm{kg}$ diet in all groups, with the exception of the male analbuminaemic rats

4. Differences in plasma colloid osmotic pressure were similar to those seen in plasma protein concentration. Interstitial colloid osmotic pressure was higher in the control rats than in the analbuminaemic ones. The interstitial colloid osmotic pressure increased during growth in the control but not in the analbuminaemic rats. The difference in interstitial colloid osmotic pressure between the strains was maintained during low-protein intake, but at a lower level than during normal protein intake.

5. Subtracting interstitial from plasma colloid osmotic pressure, resulted in a rather similar transcapillary oncotic gradient in the various groups at $75 \mathrm{~d}$, both on the control protein diet (11-14 $\mathrm{mmHg}$ ), and on the lowprotein diet $(9-11 \mathrm{mmHg})$.

6. All protein fractions were reduced to a similar extent by the low-protein diet in the control rats, whereas in the analbuminaemic rats protein fractions produced in the liver were more severely depressed.

7. Extracellular fluid volume as a percentage of body-weight was similar in all groups, and decreased with increasing age.

8. In conclusion, the analbuminaemic rats were able to maintain the transcapillary oncotic gradient on both diets by reducing the interstitial colloid osmotic pressure. Oedema was not observed.

9. Despite the absence of albumin, the protein-malnourished analbuminaemic rat is no more susceptible to hypoproteinaemia and oedema than its normal counterpart.

Hypoproteinaemia and growth retardation are well-known sequelae of protein-energy malnutrition in growing children. The clinical syndrome is called marasmus when severe growth retardation prevails, whereas in kwashiorkor the growth retardation is less severe, but is accompanied by hypoproteinaemia and oedema (Anon., 1970; Alleyne et al. 1977). What determines the development of one clinical picture rather than the other is not precisely known (Coward \& Lunn, 1981). It seems, however, that the hypoproteinaemia in kwashiorkor, which in fact concerns suppressed albumin synthesis rather than globulin synthesis, protects against development of severe growth retardation but may promote the formation of oedema (Coward, 1975).

Dietary manipulation in rats has been used extensively to investigate the aetiology of hypoproteinaemia and oedema in protein-energy malnutrition. In these animals it 
appeared that a low-protein diet inhibited growth and caused hypoproteinaemia, and that oedema occurred when plasma protein level fell to $30 \mathrm{~g} / 1$ (Edozien, 1968) or plasma colloid osmotic pressure (COP) to about $9 \mathrm{mmHg}$ (Fiorotto \& Coward, 1979). Such studies have not been done in the Nagase analbuminaemic rat (NAR), a mutant Sprague-Dawley rat strain characterized by an absolute deficiency of albumin due to a genetic defect (Nagase et al. 1979). During normal development, these rats seem to compensate for their lack of albumin by enhanced synthesis of globulins, resulting in an almost normal plasma protein concentration in adult animals (Emori et al. 1983). Conceivably this effort could be easily compromised by reducing protein supply. In that case, these animals would be more prone than normal rats to develop hypoproteinaemia and oedema during protein restriction. If this is the case, then the protein-malnourished NAR could become an interesting model for use in studies on the influence of hypoproteinaemia on volume regulation.

To assess this possibility we measured body-weight, plasma proteins, plasma and interstitial COP and extracellular fluid volume (ECFV) in young NAR and control (Sprague-Dawley) rats given normal $(200 \mathrm{~g} / \mathrm{kg})$ and low- $(60 \mathrm{~g} / \mathrm{kg})$ protein diets.

\section{METHODS}

\section{Animals}

Freshly weaned (25-d-old) Nagase analbuminaemic rats (NAR; CLEA, Tokyo, Japan) and Sprague-Dawley rats (SDR; Hsd-Ola, Harlan-CPB, Zeist, The Netherlands) were given, ad lib., semi-synthetic isoenergetic diets (Hope Farms, Woerden, The Netherlands) containing $60 \mathrm{~g}$ or $200 \mathrm{~g}$ casein-protein $/ \mathrm{kg}$. Methionine supplementation was reduced by $70 \%$ in the low-protein diet. Diet composition is shown in Table 1. Male and female rats were housed separately in groups of two to four rats. Six rats of each strain and sex were given one of the two diets, resulting in eight experimental groups. The study was approved by the Utrecht University Board for study in experimental animals.

\section{Protocol}

Rats were weighed and blood was sampled under diethyl ether anaesthesia by retroorbital puncture at $10 \mathrm{~d}$ intervals from 25 to $75 \mathrm{~d}$ of age for the determination of total protein. Albumin concentrations were determined in samples from days 25, 45 and 75 . Electrophoresis of plasma protein was performed on samples from day 75. ECFV was determined from $45 \mathrm{~d}$ of age onwards. Plasma and interstitial COP were determined at the start and end of the trial (days 25 and 75).

\section{Analytical methods}

Protein analysis. Plasma protein concentration was determined colorimetrically (Bio-Rad Lab., Munich, W. Germany). Interstitial fluid was sampled by threading two saline- ( $9 \mathrm{~g}$ sodium chloride/1) soaked nylon wicks subcutaneously on the shaven back in a longitudinal direction. The wicks were retrieved after at least $1 \mathrm{~h}$ (Joles et al. 1988). Blood-stained wicks were discarded, and non-stained wicks were spun for $20 \mathrm{~min}$ under paraffin. The COP of plasma and interstitial fluid was measured with the strain-gauge oncometer (Johnsen, 1974). The transcapillary COP gradient was calculated as the difference between the COP of plasma and interstitial fluid.

Albumin levels were determined by immunoturbidimetry using rabbit-anti-rat albumin (Nordic, Tilburg, The Netherlands). Rat albumin (Fraction V, Sigma; St Louis, Mo, USA) was used as a reference.

Plasma protein composition was analysed by polyacrylamide gel electrophoresis in the presence of sodium dodecyl sulphate (SDS-PAGE). SDS-PAGE was performed in a 
Table 1. Composition $(\mathrm{g} / \mathrm{kg})$ of the control and low-protein diets given to the rats

\begin{tabular}{lcc}
\hline Constituent & Control & Low-protein \\
\hline Casein & 200 & 60 \\
Maize starch & 80 & 80 \\
Cellulose & 50 & 50 \\
Glucose & 552 & 691 \\
Soya-bean oil & 50 & 50 \\
CaCO $_{3}$ & $18 \cdot 0$ & $14 \cdot 6$ \\
CaHPO $_{4}$ & $3 \cdot 0$ & $8 \cdot 3$ \\
$\mathrm{KH}_{2} \mathrm{PO}_{4}$ & 10 & 10 \\
$\mathrm{KCl}$ & 3 & 3 \\
$\mathrm{NaCl}$ (iodized) & 3 & 3 \\
$\mathrm{MgSO}_{4}$ & 4 & 4 \\
$\mathrm{MgO}$ & 2 & 2 \\
$\mathrm{DL}^{-M e t h i o n i n e}$ & $2 \cdot 0$ & $0 \cdot 6$ \\
Choline chloride (50\%) & 3 & 3 \\
Standard vitamins & 10 & 10 \\
Standard trace elements & 10 & 10 \\
$\quad$ Total & 1000 & 1000 \\
\hline
\end{tabular}

discontinuous system (10\% acrylamide) according to Laemmli (1970) as modified by Lanzillo et al. (1980). Staining of the gels was performed with Coomassie Blue for image analysis and with a silver staining kit (Bio-Rad Lab.) for photographic reproduction. The gels contained a mixture of the following protein standards: SDS protein standards (Bio Rad 161-0303) and protein test mixture 5 (Serva 39209).

The image analysis system consisted of the following equipment: a CCD-camera (model MX; HTH) equipped with a 1.7/17 mm lens (model Xenoplan; Schneider Kreuznach) which was modified for close-up recording (M. A. van Ingen, Department of Fine Mechanics, RIVM, Bilthoven, The Netherlands), a colour video monitor (model Trinitron PVM-1271Q/1371QM; Sony), a personal computer (M24 with a $20 \mathrm{MB}$ hard disc; Olivetti) equipped with a frame grabber (model PC vision plus; Imaging Technology Inc.) using a software package for image analysis (TIM version 3.02; Difa Measuring Systems) and a matrix printer (model FX-800; Epson).

The wet gels were placed on a high-quality illuminator (Enraf Nonius, Delft, The Netherlands). The image of the gel was subjected to automatic linear contrast stretch. The grey density values of one of the lines of the monitor through the gel were plotted by a standard command of the software.

Staining intensity as an index of concentration was compared in samples from rats of the same strain and sex given control and low-protein diets. Both band and sample (all band) intensities were compared. The staining intensity at the control protein diet was set at $100 \%$.

$E C F V$. ECFV was measured as the $60-\mathrm{min}{ }^{82} \mathrm{Br}$ distribution space (Barratt \& Walser, 1969). The isotope $(37 \mathrm{kBq})$ was injected into a tail vein in $50 \mu$ l saline.

\section{Statistical analysis}

Values were subjected to analysis of variance and a least significant difference test $(P<0.05)$. All values are expressed as means with their standard errors. 


\section{RESULTS}

Body-weight

Body-weight increased rapidly on the $200 \mathrm{~g}$ protein $/ \mathrm{kg}$ diet in both SDR and NAR. Bodyweights of male and female NAR were not significantly lower than those of SDR at $200 \mathrm{~g}$ protein $/ \mathrm{kg}$. The low-protein diet severely inhibited growth in both strains, in males (Fig. $1(a)$ ) as well as in females (Fig. $1(b)$ ). Body-weights diverged strongly at $60 \mathrm{~g}$ protein $/ \mathrm{kg}$, and at $75 \mathrm{~d}$ both male and female NAR were smaller than SDR on the lowprotein diet. Body-weight was slightly more depressed $(P=0.07)$ in the male NAR than in the male SDR on the low-protein diet. Weight reduction induced by the low-protein intake was not different in the females of the two strains $(P=0 \cdot 32)$.

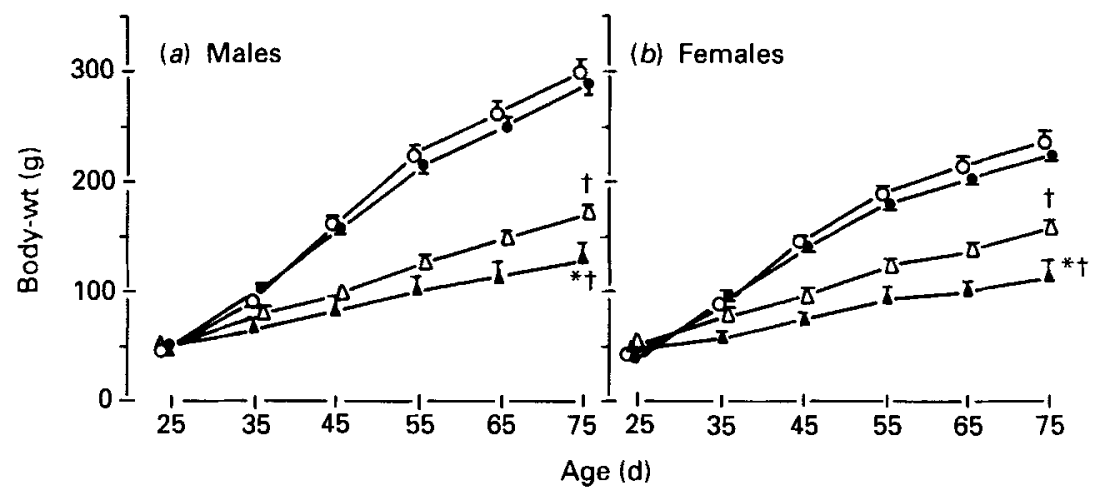

Fig. I. Body-weight (g) of growing male $(a)$ and female (b) Sprague-Dawley rats (SDR) fed on control $(200 \mathrm{~g} / \mathrm{kg} ; O)$ or low- $(60 \mathrm{~g} / \mathrm{kg} ; \triangle)$ protein diets, and Nagase analbuminaemic rats fed on control $(200 \mathrm{~g} / \mathrm{kg} ; \bigcirc)$ or low- $(60 \mathrm{~g} / \mathrm{kg} ; \Delta)$ protein diets. Points are means with their standard errors represented by vertical bars for six rats/group. * Mean values were significantly different from those for SDR rats: $P<0.05$. $\dagger$ Mean values were significantly different from those for the control diet: $P<0.05$. For details of diets and experimental procedures, see p. 486 and Table 1.

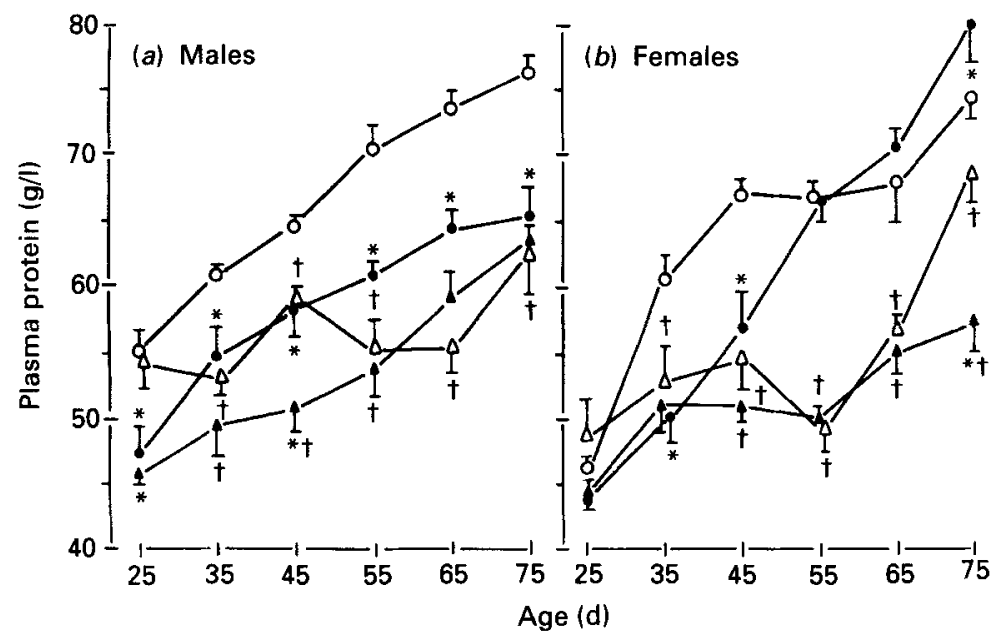

Fig. 2. Plasma protein concentration $(\mathrm{g} / \mathrm{l})$ of growing male $(a)$ and female $(b)$ Sprague-Dawley rats (SDR) fed on control $(200 \mathrm{~g} / \mathrm{kg} ; O)$ or low- $(60 \mathrm{~g} / \mathrm{kg} ; \triangle)$ protein diets, and Nagase analbuminaemic rats fed on control $(200 \mathrm{~g} / \mathrm{kg} ; 0)$ or low- $(60 \mathrm{~g} / \mathrm{kg} ; \Delta)$ protein diets. Points are means with their standard errors represented by vertical bars for six rats/group. * Mean values were significantly different from those for SDR rats: $P<0.05$. $\dagger$ Mean values were significantly different from those for the control diet: $P<0.05$. For details of diets and experimental procedures, see p. 486 and Table 1 . 


\section{Plasma protein concentration}

In all groups growth was accompanied by an increase in the plasma protein concentration. In the male NAR on the control $(200 \mathrm{~g} / \mathrm{kg})$ diet plasma protein concentration was decreased compared with SDR at all ages after weaning (Fig. $2(a)$ ). In the female NAR (Fig. $2(b)$ ) plasma protein concentration was lower than that in female SDR at 35 and $45 \mathrm{~d}$ of age only. In fact on day 75 the plasma protein concentration was significantly higher in female NAR than in female SDR. The low-protein diet caused considerable depression of plasma protein concentration in both male and female SDR as well as the female NAR in comparison with the values found in the same groups on the control protein diet (Fig. $2(a, b))$. In the male NAR, however, there was much less depression of plasma protein concentration by the low-protein diet. In fact, at 65 and $75 \mathrm{~d}$ of age the mean protein concentration was slightly higher than that of the male SDR on the $60 \mathrm{~g} / \mathrm{kg}$ diet (not significant).

COP

Plasma. A few days after weaning plasma COP in both males and females was higher in the SDR than in the NAR. Plasma COP increased in all groups. The difference between the strains was maintained at $75 \mathrm{~d}$ in the males but, due to the large increase in NAR, it was strongly reduced in the females (Table 2). On the low-protein intake plasma COP also

Table 2. Plasma and interstitial colloid osmotic pressure $(C O P ; m m H g)$ and the transcapillary COP gradient (plasma COP-interstitial COP) in male and female Sprague-Dawley rats $(S D R)$ and Nagase analbuminaemic rats $(N A R)$ given 200 or $60 \mathrm{~g}$ protein $/ \mathrm{kg}$ diets

(Mean values with their standard errors for six rats/group)

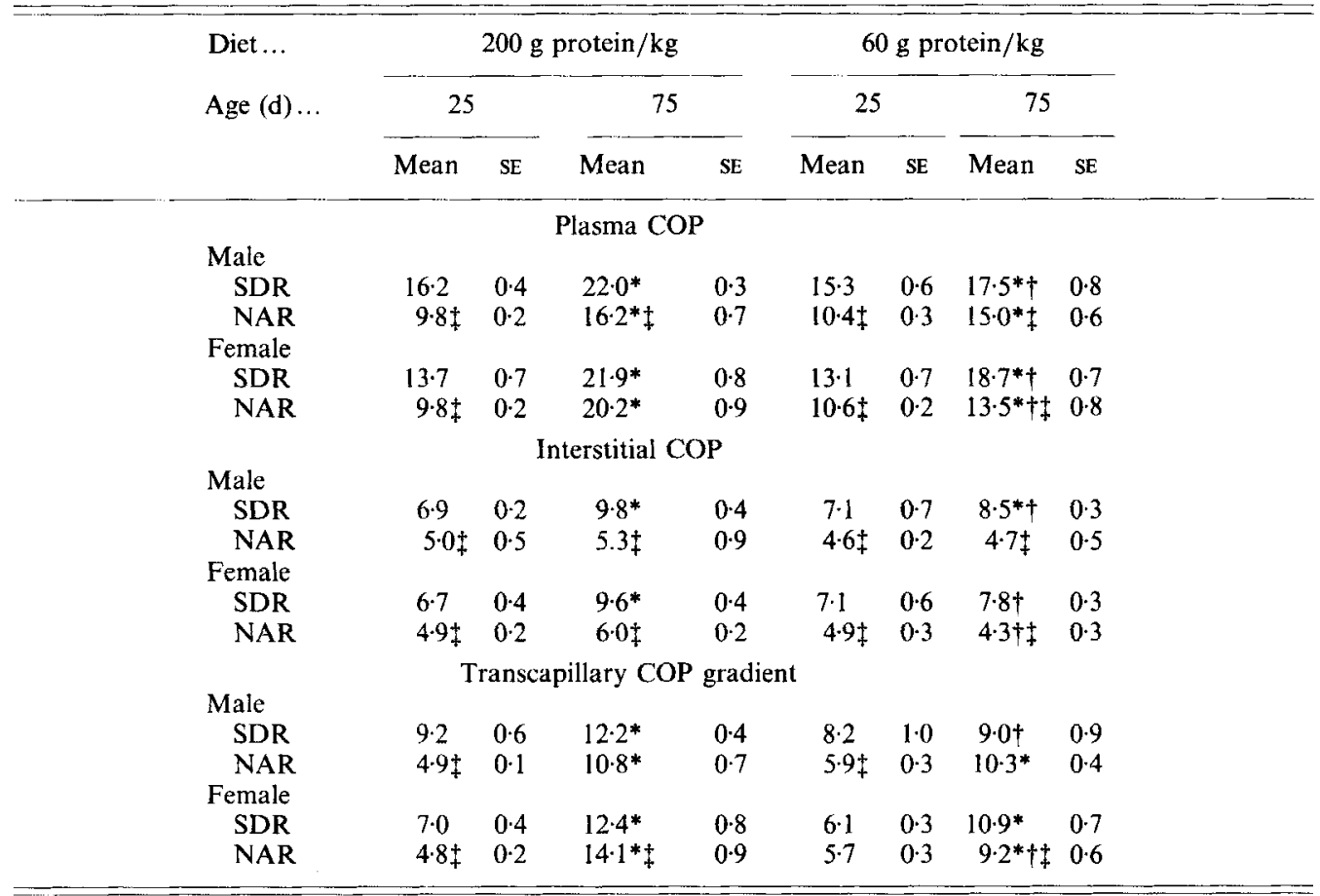

* Mean values at $75 \mathrm{~d}$ of age were significantly different from those at $25 \mathrm{~d}$ of age $P<0.05$.

$\dagger$ Mean values for $60 \mathrm{~g} / \mathrm{kg}$ diet were significantly different from those for $200 \mathrm{~g} / \mathrm{kg}$ diet $: P<0.05$.

$\ddagger$ Mean values for NAR were significantly different from those for SDR: $P<0.05$. 
increased during growth in all groups, but in the male and female SDR and the female NAR the value at $75 \mathrm{~d}$ was significantly depressed compared with the increase on the control diet. However, a non-significant reduction of only about $1 \mathrm{mmHg}$ was measured in the male NAR on the low-protein diet compared with the control diet.

Interstitial fluid. As in plasma, interstitial fluid COP was higher in SDR than in NAR directly after weaning (Table 2). However, in the NAR interstitial fluid COP failed to increase significantly during growth as it did in the SDR. On the low-protein diet the interstitial fluid COP measured in the SDR at $75 \mathrm{~d}$ was somewhat higher than the value found at $25 \mathrm{~d}$, although this difference was dampened compared with the rise on the control diet. Once again, no increase in interstitial COP was observed during growth in the NAR. In fact it had decreased slightly in the female NAR at $75 \mathrm{~d}$ compared with the age-matched NAR on the control protein intake.

Transcapillary COP gradient. The transcapillary COP gradient, which is the difference between plasma and interstitial COP, was lower in the newly weaned NAR compared with the SDR (Table 2). Both strains showed an increase in the gradient during growth. However, the gradients were rather similar in the two strains at $75 \mathrm{~d}$ due to the fact that in the NAR the plasma COP increased much more than insterstitial COP. On the lowprotein diet the gradient increased less during growth, particularly in the male SDR and the female NAR, due to the smaller increase in plasma COP. In fact in the female NAR this caused a gradient which was lower than that found in the female SDR, which was the reverse of the situation at $75 \mathrm{~d}$ on the $200 \mathrm{~g}$ protein $/ \mathrm{kg}$ diet.

\section{Plasma albumin concentration}

Albumin was consistently below the detection limit $(<0.2 \mathrm{~g} / 1)$ in all NAR samples. At $45 \mathrm{~d}$ it was reduced to 26 (SE 1) $\mathrm{g} / \mathrm{l}$ in the SDR at low-protein intake, compared with 30 (SE 1$) \mathrm{g} / 1$ at $200 \mathrm{~g}$ protein $/ \mathrm{kg}(P<0.01$ ), and at $75 \mathrm{~d}$ to 30 (SE 1$) \mathrm{g} / 1$ (control 35 (SE 1) $\mathrm{g} / 1$; $P<0.01)$.

\section{Plasma protein composition}

The protein spectrum, compared with that of the SDR, was markedly altered in the NAR (Plate 1). Albumin was absent, and several other fractions showed an increased staining intensity. There were no differences in protein spectrum in the SDR on the control and lowprotein diets. In the male and female NAR the $60 \mathrm{~g}$ protein $/ \mathrm{kg}$ diet caused a reduction of 24 (SE 4) \% in the staining intensity of four clearly defined bands with molecular weights of 11700 (haptoglobin $\alpha-1$ chains), 78000 (transferrin), 165000 ( $\alpha$-2-macroglobulin) and 200000 (unidentified). In addition, male NAR on the $60 \mathrm{~g} / \mathrm{kg}$ diet showed a reduction in the staining intensity in two bands with molecular weights of 26000 (apolipoprotein AI) and 57000 ( $\alpha$-1-acid glycoprotein). All these proteins were tentatively identified as being the most likely candidates using a two-dimensional map for human serum proteins (Daufeldt \& Harrison, 1984).

\section{$E C F V$}

There were no significant differences in ECFV between any of the groups (Fig. 3). ECFV as a percentage of body-weight decreased with increasing age (for all measurements: ECFV $=-0.25$ age $(\mathrm{d})+54 ; r 0.458, P<0.01)$. Oedema was not observed. 


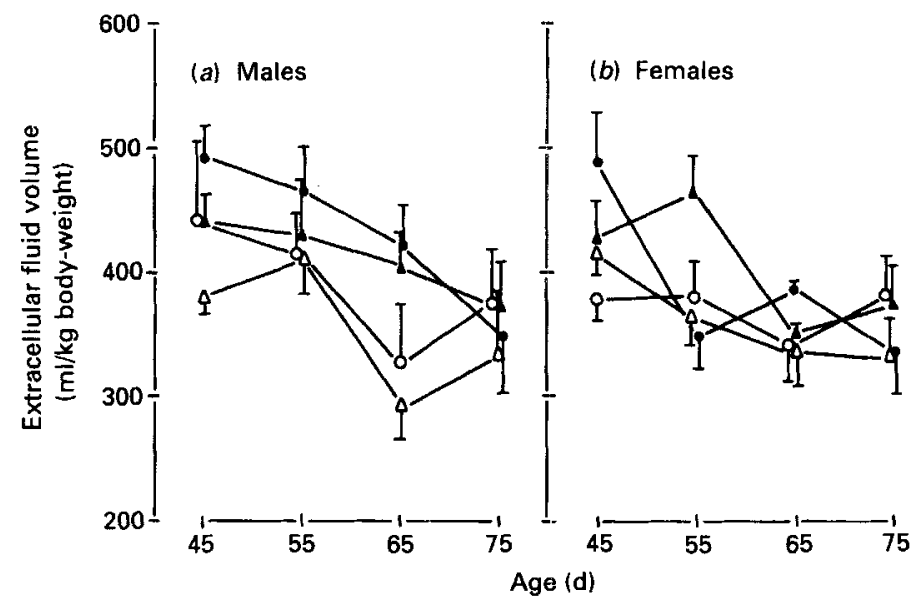

Fig. 3. Extracellular fluid volume ( $\mathrm{ml} / \mathrm{kg}$ body-weight) of growing male $(a)$ and female $(b)$ Sprague Dawley rats fed on control $(200 \mathrm{~g} / \mathrm{kg} ; 0)$ or low- $(60 \mathrm{~g} / \mathrm{kg} ; \triangle)$ protein diets, and Nagase analbuminaemic rats fed on control $(200 \mathrm{~g} / \mathrm{kg} ; \bigcirc)$ or low- $(60 \mathrm{~g} / \mathrm{kg} ; \boldsymbol{\Delta})$ protein diets. Points are means with their standard errors represented by vertical bars for six rats/group. For details of diets and experimental procedures, see p. 487 and Table 1.

\section{DISCUSSION}

Low-protein diet effects on growth and plasma protein concentration

The low-protein diet caused considerable growth retardation in both strains. The degree of growth retardation was not different in the females. However, the reduction in body-weight was slightly more pronounced in the male NAR (about $50 \%$ ) compared with the male SDR (about $40 \%$ ). Thus, the effects of protein restriction on growth seem to be modulated by sex. The physiological increase in plasma protein concentration during ageing was also attenuated by the low-protein diet. For this variable the decrease was most pronounced in the female NAR, whereas in the male NAR final plasma protein concentration was hardly affected by the low-protein intake. Thus the reaction of plasma protein levels to protein restriction are also affected by sex in NAR, but in the opposite direction. In the male NAR on the control diet the plasma protein concentration was maintained about $8 \mathrm{~g} / \mathrm{l}$ below that of the male SDR. In the females, however, the plasma protein levels rose steeply in the NAR, reaching a final level which, in fact, was higher than that in the SDR. This confirms previous observations on plasma protein concentrations in NAR (Emori et al. 1983). Apparently, the compensatory protein production in female NAR is of a greater magnitude than in males. However, only in females is this compensatory increase sensitive to protein restriction. Changes in plasma protein spectrum (see p. 492) suggest oestrogen dependence of this component.

\section{Low-protein diet effects on plasma protein spectrum}

Plasma albumin levels dropped significantly in the SDR on the low-protein diet, as has been seen in many previous studies (Kirsch et al. 1968; Coward \& Sawyer, 1977; Lunn \& Austin, 1983). However, this fall could only account for part of the fall in total plasma protein concentreation in the SDR. Electrophoresis of plasma proteins indicated little change in the protein spectrum in the SDR on the low-protein diet, all fractions being more or less equally reduced. Emori et al (1983) found that in the female NAR on a normal diet high levels of transferrin and caeruloplasmin were maintained by oestrogen. In the protein- 
deprived NAR the contribution of transferrin to total plasma protein decreased. The latter was particularly decreased by low-protein supply in the female NAR. Thus, this oestrogendependent production seems to be sensitive to a low-protein supply.

Besides transferrin, high levels of $\alpha$-2-macroglobulin and $\alpha$-1-acid glycoprotein have also previously been reported in NAR (Esumi et al. 1979; Emori et al. 1983), and contribute importantly towards the total plasma protein concentration in this mutant rat strain. Enhanced synthesis of transferrin in NAR hepatocytes (Sugiyama et al. 1982), as well as raised transferrin mRNA in NAR liver (Sugiyama et al. 1987) have been described. Presumably the synthesis of the other protein fractions is also increased, as has also been reported in hypoalbuminaemic rats with induced nephrosis (Lewandowski et al. 1988). This compensatory mechanism, which is clearly utilized by NAR under normal circumstances, is apparently only partly affected by protein deprivation, at least at the level used in the present study.

\section{Changes in oncotic pressure and ECFV during growth}

In the steady state there is a dynamic equilibrium between plasma and interstitial protein pools (Aukland \& Nicolaysen, 1981; Renkin, 1986). Thus when plasma COP is low, interstitial COP will also be low. Indeed, in 25-d-old male and female SDR, plasma and interstitial COP were both lower than the respective values at $75 \mathrm{~d}$. However, the difference between the oncotic pressures in the two compartments, which is the transcapillary COP gradient, was smaller at $25 \mathrm{~d}$. A low gradient, if not balanced by changes in other Starling forces, will result in an increase in interstitial volume (Aukland \& Nicolaysen, 1981). Possibly this low gradient is the reason why the extracellular ECFV tends to be higher in the young rat, as was observed in the present study and by Fiorotto \& Coward (1979), who also measured a lower oncotic gradient in 7-week-old rats compared with rats of 9 and 12 weeks of age. Similarly, falls in ECFV have been recorded in the first year of life in infants (Hanna, 1963).

The low oncotic gradient may be related to the fact that the plasma protein spectrum in the postnatal period is dominated by low-molecular-weight molecules such as $\alpha$-fetoprotein (Esumi et al. 1982) with a relatively low reflection coefficient (Renkin, 1986). The result is a relatively low plasma COP and a relatively high interstitial COP. In the course of growth the production of high-molecular-weight substances, such as albumin (Cartlidge \& Rutter, 1986), and other large molecules with higher reflection coefficients, increases rapidly, and thus plasma COP rises steeply whereas interstitial COP lags behind. Indeed, at $75 \mathrm{~d}$ substantial increases had occurred in plasma COP in SDR and NAR, whereas interstitial COP rose much less. In fact, in the NAR the interstitial COP did not increase at all. Thus, the rise in interstitial COP in the SDR is probably largely due to increasing interstitial albumin concentrations. The net result of all these changes was a transcapillary COP gradient which varied within rather narrow limits $(11-14 \mathrm{mmHg})$ in all groups at $75 \mathrm{~d}$ of age. Consequently intra- and extravascular fluid distribution will probably be similar at this age, which was supported by a small range in ECFV (Fig. 3).

\section{Low-protein diet effects on oncotic pressures and extracellular fluid volume}

As mentioned previously, in male NAR the low-protein diet had no effect on plasma and interstitial COP. In all the other groups both plasma and interstitial COP decreased. Because the absolute reduction of interstitial COP was less than that of the plasma COP, the gradient was also decreased in all except the male NAR subgroup. As a result the gradient became very similar in all the subgroups $(9-11 \mathrm{mmHg})$. This transcapillary COP gradient was clearly high enough to maintain normal fluid partition as oedema was not observed in either NAR or SDR.

In contrast to our findings, oedema formation in rats was reported by Edozien (1968) and 
Fiorotto \& Coward (1979), both supplying a $5 \mathrm{~g}$ casein $/ \mathrm{kg}$ diet for 3-5 months. At this stage the transcapillary gradient was about $8 \mathrm{mmHg}$ (Fiorotto \& Coward, 1979) which is only marginally under the level we found. However, since mortality was considerable (Edozien, 1968) and, before oedema appeared, the animals had lost a considerable amount of weight (30-40\%) compared with an increase of weight in the age-matched control group of about $350 \%$ (Edozien, 1968; Fiorotto \& Coward, 1979), fluid retention in these studies may have been linked to morbid factors other than hypoproteinaemia. Such low-protein intakes and negative growth rates do not model human kwashiorkor. In the present study protein intake was set at a level similar to that found in communities where kwashiorkor (and marasmus) occur (Coward \& Lunn, 1981). However, oedema did not develop in either the analbuminaemic or the control rats. The reason for this discrepancy is unclear, and the actual cause of oedema in kwashiorkor remains unknown. One of the most important factors in the prevention of oedema in chronic hypoproteinaemia is a reduction in interstitial COP, thus partly preserving the transcapillary oncotic gradient (Aukland \& Nicolaysen, 1981). In the present study such a reduction was clearly observed. This phenomenon has previously been observed in rats with dietary hypoproteinaemia (Fiorotto \& Coward, 1979), during protein depletion in dogs using a combination of plasmaphoresis and a low-protein diet (Joles et al. 1988), and in rats (Fadnes, 1975) and humans (Noddeland et al. 1982) with the nephrotic syndrome. In children with kwashiorkor very low protein concentrations have been recorded in oedema fluid (Tripathi et al. 1983), but interstitial COP has not yet been documented.

In conclusion, in the NAR the development of hypoproteinaemia is not more pronounced in protein-energy malnutriton than in control rats. Oedema formation is prevented by changes in interstitial COP which are parallel to those seen in the plasma.

The authors thank Dr S. Nagase for generously supplying the analbuminaemic rats. This study was supported by the Dutch Kidney Foundation.

\section{REFERENCES}

Alleyne, G. A. O., Hay, R. W., Picou, D. I., Stanfield, J. P. \& Whitehead, R. G. (1977). Protein-Energy Malnutriton, pp. 1-7. London: Edward Arnold.

Anon. (1970). Classification of infantile malnutrition. Lancet ii, 302-303.

Aukland, K. \& Nicolaysen, G. (1981). Interstitial fluid volume: local regulatory mechanisms. Physiological Reviews 61, 556-643.

Barratt, T. M. \& Walser, M. (1969). Extracellular fluid in individual tissues and in whole animals: the distribution of radiosulphate and radiobromide. Journal of Clinical Investigation 48, 56-66.

Cartlidge, P. H. T. \& Rutter, N. (1986). Serum albumin concentrations and oedema in the newborn. Archives of Disease in Childhood 61, 656-660.

Coward, W. A. (1975). Serum colloidal osmotic pressure in the development of kwashiorkor and in recovery: its relationship to albumin and globulin concentrations and oedema. British Journal of Nutrition 34, 459-467.

Coward, W. A. \& Lunn, P. G. (1981). The biochemistry and physiology of kwashiorkor and marasmus. British Medical Bulletin 37, 19-24.

Coward, W. A. \& Sawyer, M. B. (1977). Whole-body albumin mass and distribution in rats fed on low-protein diets. British Journal of Nutrition 37, 127-134.

Daufeldt, J. A. \& Harrison, H. H. (1984). Quality control and technical outcome of iso-dalt two-dimensional electrophoresis in a clinical laboratory setting. Clinical Chemistry 20, 1972-1980.

Edozien, J. C. (1968). Experimental kwashiorkor and marasmus. Nature 220, 917-919.

Emori, T., Takahashi, M., Sugiyama, K., Shumiya, S. \& Nagase, S. (1983). Age-related changes in plasma proteins of analbuminemic rats. Experimental Animals 32, 123-132.

Esumi, H., Sato, S., Ouki, M., Sugimura, T. \& Nagase, S. (1979). Turnover of serum proteins in rats with analbuminemia. Biochemical and Biophysical Research Communications 87, 1191-1199.

Esumi, H., Takahashi, Y., Seki, M., Sato, S., Nagase, S. \& Sugimura, T. (1982). Perinatal changes of $\alpha$-fetoprotein concentration in the serum and its synthesis in the liver of analbuminemic rats. Cancer Research 42, 306-308.

Fadnes, H. O. (1975). Protein concentration and hydrostatic pressure in subcutaneous tissue of rats in hypoproteinemia. Scandinavian Journal of Clinical and Laboratory Investigation 35, 441-446. 
Fiorotto, M. \& Coward, W. A. (1979). Pathogenesis of oedema in protein-energy malnutrition: the significance of plasma colloid osmotic pressure. British Journal of Nutrition 42, 21-31.

Hanna, F. M. (1983). Changes in body composition of normal infants in relation to diet. Annals of the New York Academy of Sciences 110, 840-848.

Johnsen, H. M. (1974). Measurement of colloid osmotic pressure of interstitial fluid. Acta Physiologica Scandinavica 91, 142-144.

Joles, J. A., Koomans, H. A., Kortlandt, W., Boer, P. \& Dorhout Mees, E. J. (1988). Hypoproteinemia and recovery from edema in dogs. American Journal of Physiology 254, F887-F894.

Kirsch, R., Frith, L., Black, E. \& Hoffenberg, R. (1968). Regulation of albumin synthesis and catabolism by alteration of dietary protein. Nature 217, 578-579.

Laemmli, U. K. (1970). Cleavage of structural proteins during the assembly of the head of bacteriophage T4. Nature 227, 680-687.

Lanzillo, J. J., Stevens, J. \& Fanburg, B. L. (1980). A comparison of commonly used discontinuous and continuous buffer systems for electrophoresis in sodium dodecyl sulphate containing polyacrylamide gels. Electrophoresis 1, 180-186.

Lewandowski, A. E., Liao, W. S. L., Stinton-Fisher, C. A., Kent, J. D. \& Jefferson, L. S. (1988). Effects of experimentally induced nephrosis on protein synthesis in the rat liver. American Journal of Physiology 254, C634 C642.

Lunn, P. G. \& Austin, S. (1983). Dietary manipulation of plasma albumin concentration. Journal of Nutrition 113 , 1791-1802.

Nagase, S., Shimamune, K. \& Shumiya, S. (1979). Albumin-deficient rat mutant. Science 205, 590-591.

Noddeland, H. S., Riisness, S. M. \& Fadnes, H. O. (1982). Interstitial fluid colloid osmotic and hydrostatic pressures in subcutaneous tissue of patients with the nephrotic syndrome. Scandinavian Journal of Clinical and Laboratory Investigation 42, 139-146.

Renkin, E. M. (1986). Some consequences of capillary permeability to macromolecules: Starling's hypothesis reconsidered. American Journal of Physiology 250, H706-H710.

Sugiyama, K., Emori, T. \& Nagase, S. (1982). Synthesis and secretion of plasma protein by isolated hepatocytes of analbuminemic rats. Journal of Biochemistry 92, 775-779.

Sugiyama, K., Izumi, S., Tomino, S. \& Nagase, S. (1987). A high level of transferrin mRNA in the liver of analbuminemic rats. Journal of Biochemistry 102, 967-970.

Tripathi, A. M., Agrawal, K. K. \& Agarwal, K. N. (1983). Oedema fluid composition in childhood disorders. Acta Paediatrica Scandinavica 72, 741-745.

\section{EXPLANATION OF PLATE}

Plate 1. SDS-polyacrylamide gel electrophoresis of plasma proteins from 75-d-old Sprague-Dawley rats (SDR) and Nagase analbuminaemic rats (NAR). The molecular weights (kDa) of a mixture of protein standards are indicated. (1), Female, SDR, $60 \mathrm{~g}$ protein $/ \mathrm{kg}$ diet; (2), male, SDR, $60 \mathrm{~g}$ protein $/ \mathrm{kg}$ diet; (3), female, SDR, $200 \mathrm{~g}$ protein $/ \mathrm{kg}$ diet; (4), male, SDR, $200 \mathrm{~g}$ protein $/ \mathrm{kg}$ diet; (5), protein standards; (6), female, NAR, $60 \mathrm{~g}$ protein $/ \mathrm{kg}$ diet; (7), male, NAR, $60 \mathrm{~g}$ protein $/ \mathrm{kg}$ diet; (8), female, NAR, $200 \mathrm{~g}$ protein $/ \mathrm{kg}$ diet; (9), male, NAR, $200 \mathrm{~g}$ protein $/ \mathrm{kg}$ diet; (10), protein standards. For details of procedures, see p. 487. 
British Journal of Nutrition, Vol. 61, No. 3

Plate 1

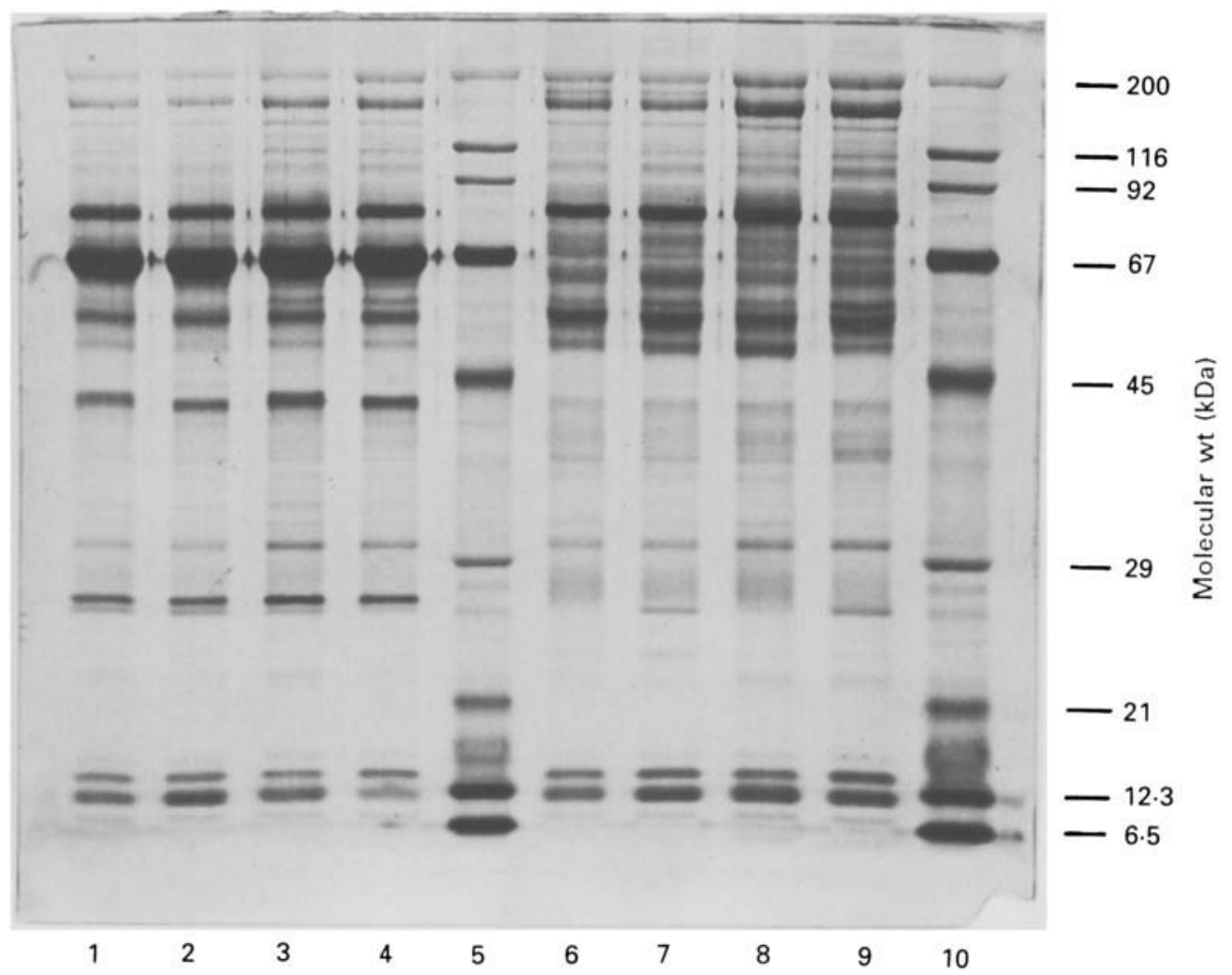

